\title{
Synthesis and Crystal Structure of a New Quaternary Chalcoantimonide: $\mathrm{KLa}_{2} \mathrm{Sb}_{3} \mathrm{~S}_{9}$ and $\mathrm{KSm}_{2} \mathrm{Sb}_{3} \mathrm{Se}_{8}$
}

\author{
Sung-Jin Kim, Sunju Park, and Sunah Yim \\ Department of Chemistr, Ewha Homans Cniversit;, Seoul 120-750, Korea \\ Received Julv 11, 2003
}

\begin{abstract}
Silver-needle shaped crystals of $\mathrm{KLa}_{2} \mathrm{Sb}_{3} \mathrm{~S}_{9}$ from $\mathrm{K}_{2} \mathrm{~S}_{\mathrm{x}}$ flux and $\mathrm{KSm_{2 }} \mathrm{Sb}_{3} \mathrm{Se}_{8}$ from $\mathrm{NaCl} / \mathrm{KCl}$ flux reactions were obtained and their crystal structures were determined by the single crystal X-ray diffraction method. $\mathrm{KLa}_{2} \mathrm{Sb}_{3} \mathrm{~S}_{9}$ crystallizes in the orthorhombic noncentrosymmetric space group $\mathrm{P}_{2} 2_{1} 2_{1}$ (No. 19 ) with a unit cell of $\mathrm{a}=4.220(3) \AA . \mathrm{b}=24.145(2) \AA . c=14.757(5) \AA$ and $Z=4 . \mathrm{KSm}_{-} \mathrm{Sb}_{3} \mathrm{Se}_{8}$ crystallizes in the orthorhombic space group Pnma (No.62) with a unit cell of $a=16.719(3) \AA . b=4.1236(8) \AA . c=22.15 \mathrm{l}(4) \AA$ and $Z=4$. Both structures have three-dimensional tumel frameworks filled with $\mathrm{K}^{+}$ions. $\mathrm{KSm}_{2} \mathrm{Sb}_{3} \mathrm{Se}_{8}$ is an ordered version of $\mathrm{ALn}_{1}={ }_{\mathrm{X}} \mathrm{Bi}_{4 \pm \times} \mathrm{S}_{8}$, and it is made up of $\mathrm{NaCl}$-type and $\mathrm{Gd}_{2} \mathrm{~S}_{3}$-tỵpe fragments. $\mathrm{KL} \mathrm{a}_{2} \mathrm{Sb}_{3} \mathrm{~S}_{9}$ also contains building fragments similar to those of $\mathrm{KSm}_{2} \mathrm{Sb}_{3} \mathrm{Se}_{8}$. however. there are chalcogen-chalcogen bonds in the $\mathrm{Gd}_{2} \mathrm{~S}_{3}$-type fragment. The formula of $\mathrm{KLa}_{2} \mathrm{Sb}_{3} \mathrm{~S}_{9}$ can be described as $\left(\mathrm{K}^{-}\right)\left(\mathrm{La}^{2+}\right)\left(\mathrm{Sb}^{2-}\right)_{5}\left(\mathrm{~S}^{--}\right)-\left(\mathrm{S}_{2}{ }^{2-}\right)$.
\end{abstract}

Key Words : Quaternary chalcoantimonide. Rare-earth quaternary. Flux $\mathrm{Gd}_{2} \mathrm{~S}_{\mathbf{s}}$-type, Chalcogen-chalcogen bond

\section{Introduction}

Many ternary chalcoantimonides of alkaline or alkaline earth. main group metals and transition metals with various structures have been synthesized. ${ }^{1-3}$ Rich structural variations in these compounds are derived from the stereochemically active Sb lone pair electrons. ${ }^{+}$Along with the coordinate character of $\mathrm{Sb}$. it is expected that the addition of large electropositive cations such as lanthanides into $\left[\mathrm{Sb}_{\mathrm{X}} \mathrm{Q}_{\mathrm{y}}\right]^{13-}$ building blocks leads to new compounds with a more complex structure. Especially, rare-earth elentents may cause unique metal-chalcogen bonding characters due to their large size and high coordination numbers. This strategy also has been applied to synthesize novel multinary chalcoantimonides and some of ternary rare-earth antimony chalcogenides have been reported. ${ }^{5}$

Compared to the diversity of the ternary $\mathrm{Bi}$ and $\mathrm{Sb}$ chalcoantimonide compounds. rare-earth quaternary phases in this class are quite limited. Reported rare-earth chalcoantimonides are $\mathrm{K}_{2}(\mathrm{RE})_{2 . .} \mathrm{Sb}_{4+\mathrm{x}} \mathrm{Se}_{12}\left(\mathrm{RE}=\mathrm{La}, \mathrm{Ce}\right.$. Pr. Gd). ${ }^{6}$ $\mathrm{AU}_{2} \mathrm{SbQ}_{\mathrm{S}}\left(\mathrm{A}=\mathrm{K} . \mathrm{Rb} ; \mathrm{Q}=\mathrm{S}\right.$. Se). ${ }^{7} \mathrm{KThSb}_{-} \mathrm{Se}_{6 .}{ }^{8} \mathrm{~K}_{2} \mathrm{Gd}_{2} \mathrm{Sb}_{2} \mathrm{Se}_{9}$ $\mathrm{K}_{2} \mathrm{La}_{2} \mathrm{Sb}_{2} \mathrm{~S}_{9}{ }^{9}$ and $\mathrm{Na}_{9} \mathrm{Gd}_{5} \mathrm{Sb}_{8} \mathrm{~S}_{26}{ }^{10}$ and $\mathrm{Bi}$ compounds are $\mathrm{BaLaBi}_{2} \mathrm{~S}_{6}{ }^{8} \mathrm{Eu}_{2} \mathrm{~Pb}_{2} \mathrm{Bi}_{6} \mathrm{Se}_{13},{ }^{11}$ and $\mathrm{ALn}_{1=\mathrm{X}} \mathrm{Bi}_{4 \pm \mathrm{K}} \mathrm{S}_{8}(\mathrm{~A}=\mathrm{K}$. Rb: Lnl=La, Ce. Pr. Nd) ${ }^{12}$ Here we report on the synthesis and structure of the new quaternary rare-earth chalcoantimonides, $\mathrm{KLa}_{2} \mathrm{Sb}_{3} \mathrm{~S}$ ind $\mathrm{KSm}_{2} \mathrm{Sb}_{3} \mathrm{Se}_{8}$.

\section{Experimental Section}

Synthesis. $\mathrm{KLa}_{2} \mathrm{Sb}_{3} \mathrm{~S}_{9}$ was prepared from the mixtures of $\sim 0.127 \mathrm{~g}$ of $\mathrm{K}_{2} \mathrm{~S}_{\mathrm{x}} 1.13 \mathrm{mmol}$ of La chips (99.9\% Aldrich). $4.54 \mathrm{~mm}$ ol of $\mathrm{Sb}$ powder $(99.999 \%$ Kojundo) and 11.35 mnol of $\mathrm{S}$ powder $\left(99.998 \%\right.$ Aldrich). $\mathrm{K}_{2} \mathrm{~S}_{\mathrm{K}}$ was synthesized by a reaction of $\mathrm{K}$ metal $(99.9 \%$ Farco Chemical) and $\mathrm{S}$ powder in liquid $\mathrm{NH}_{3}$. The reacting nixture was loaded in a quartz tube and then doubly sealed in a ligh vacuum. The mixture was heated slowly up to $700^{\circ} \mathrm{C}$. kept for 10 days. and cooled to room temperature by lowering it at a rate of 2 ${ }^{\circ} \mathrm{C} / \mathrm{hr}$. Silver-needle shaped $\mathrm{KLa}_{2} \mathrm{Sb}_{3} \mathrm{~S}_{9}$ crystals were obtained after washing the product with DMF. ethanol and distilled water to remove an excess flux, and were then dried in an oven.

$\mathrm{KS} \mathrm{S}_{2} \mathrm{Sb}_{3} \mathrm{Se}_{8}$ was prepared from a mixture of $0.55 \mathrm{mmol}$ Sin chips (99.9\% Aldrich), $1.09 \mathrm{mmol}$ of $\mathrm{Sb}_{2} \mathrm{Se}_{3}$ powder, $1.20 \mathrm{mmol}$ of Se shots $(99.99 \%$ Aldrich) with $-1.5 \mathrm{~g}$ of a 1 : 1 mixture of $\mathrm{NaCl} / \mathrm{KCl}$ flux. $\mathrm{Sb}_{2} \mathrm{Se}_{3}$ was directly synthesized by heating a stoichiometric nixture of $\mathrm{Sb}$ powder (99.999\%. Kojundo) and Se shots. The reacting mixture was loaded in a quartz tube and then doubly sealed in a high vacuum. The mixture was slowly heated up to $750^{\circ} \mathrm{C}$, kept for 10 days, and then cooled to room temperature by lowering it at a rate of $2^{\circ} \mathrm{C} / \mathrm{hr}$. Silver needle crystals were obtained by washing the product with distilled water to remove an excess flux, and were then dried in an oven.

The existence of four elements was confirmed qualitatively by an energy-dispersive X-ray (EDX) spectrometer equipped with an electron probe microanalysis (EPMA; JXA-9600, EDX: LinkeXL). Once the stoichiometries were determined, $\mathrm{KLa}_{2} \mathrm{Sb}_{2} \mathrm{~S}_{9}$ was prepared rationally as a single phase starting from the exact stoichiometry ratio of the elements and the excess flux of $\mathrm{K}_{2} \mathrm{~S}_{\mathrm{S}}$ in an evacuated quartz tube. $\mathrm{KSm}_{2} \mathrm{Sb}_{2} \mathrm{Se}_{8}$ was prepared from $\mathrm{NaCl} / \mathrm{KCl}$ flux with some unknown minor plases. However, almost the single phase of $\mathrm{KSm}_{2} \mathrm{Sb}_{2} \mathrm{Se}_{8}$ was nearly obtained when $\mathrm{K}_{2} \mathrm{Se}$ flux was used.

$\mathrm{X}$-ray Crystallography. Silver-needle shaped $\mathrm{KLa}_{2} \mathrm{Sb}_{2} \mathrm{~S}_{9}$ crystals were obtained and their crystal structure was determined by the single crystal X-ray diffraction method. A preliminary examination and data collection were performed with $\mathrm{Mo} \mathrm{K} \alpha_{1}$ radiation $(\lambda=0.71073 \AA$ ) on an Enraf Nonius diffractormeter (CAD4) equipped with an incident beam 
monochromatic graphite crystal. The unit cell parameters and orientation matrix for data collection were obtained from the least-square refinement, using the setting angles of 25 reflections in the range of $18^{\circ}<2 \theta(\mathrm{MoK})<25^{\circ}$. The observed Laue symmetry and systematic extinction suggested the noncentrosynumetric space group $\mathrm{P} 2_{1} 2_{1} 2_{1}$ for $\mathrm{KLa}_{2} \mathrm{Sb}_{3} \mathrm{~S}_{9}$. The thermal parameters of $\mathrm{S}(8)$ and $\mathrm{S}(9)$ were high $\left(0.070 \AA^{3}\right)$ compared to the other sulfur atoms. Significant electron densities at distances of $0.64(1) A$ and $0.64(1) \AA$ from $S(8)$ and $S(9)$ were found. respectively, and the two electron density peaks were assigned as $S(10)$ and $S(11)$. When the sum of the occupancies of $S(8)$ and $S(10)$ were constrained equal to $100 \%$, their partial occupancies converged to $51 \%$ and $49 \%$. respectively, and the occupancies of both $\mathrm{S}(9)$ and $\mathrm{S}(\mathrm{ll})$ converged to $50 \%$ under the $100 \%$ constraint for the sum. Since we did not observe enough extra reflections from several larger crystals having a much longer exposure period. we exclude the possibility of a superstructure due to an ordering of S atoms.

The final cycle of refinement performed on $\mathrm{F}_{0}{ }^{2}$ with 2609 unique reflections converged to the residuals w $R_{2}\left(F_{i j} \hat{2}>0\right)=$ 0.1434 and conventional $R$ index based on the reflections having $\mathrm{F}_{i^{2}}{ }^{2}>2 \sigma\left(\mathrm{F}_{i j}{ }^{2}\right) 0.0515$. The complete data collection parameters and details of structure solution and refinement results are given in Table 1 . The final atonic positions. displacement parameters. and isotropic displacement parameters are shown in Table 2. Selected bond distances and angles are listed in Table 3.

Silver-needle shaped $\mathrm{KSn}_{2} \mathrm{Sb}_{3} \mathrm{Se}_{8}$ crystals were obtained

Table 1. Crystallographic Data of $\mathrm{KLa}_{2} \mathrm{Sb}_{3} \mathrm{Su}_{0}$ and $\mathrm{KS}_{2} \mathrm{~N}_{2} \mathrm{Sb}_{3} \mathrm{Ses}$

\begin{tabular}{|c|c|c|}
\hline Empirical formula & $\mathrm{KLa}_{2} \mathrm{Sb}_{3} \mathrm{~S}_{0}$ & $\mathrm{KSm}_{2} \mathrm{Sb}_{3} \mathrm{Se}_{8}$ \\
\hline Formula weight & 970.71 & 1336.73 \\
\hline Temperature $(\mathrm{K})$ & $293(2)$ & $293(2)$ \\
\hline Wavelength $(\lambda=\mathrm{K} \alpha, A)$ & 0.71073 & 0.71073 \\
\hline Cristal sistem & Orthorhombic & Orthorhombic \\
\hline Space group & $\mathrm{P} 2,2,2$, (No.19) & Puma (No.62) \\
\hline \multirow[t]{3}{*}{ Unit cell dimensions $(A)$} & $a=4.220(3)$ & $\mathrm{a}=16.719(3)$ \\
\hline & $\mathrm{b}=24.145(2)$ & $b=4.1236(8)$ \\
\hline & $c=14.757(5)$ & $c=22.151(4)$ \\
\hline Volume $\left(A^{3}\right)$ & $1503.6(13)$ & $1527.1(5)$ \\
\hline Z & 4 & 4 \\
\hline Calculated density $\left(\mathrm{g} / \mathrm{cm}^{3}\right)$ & 4.288 & 5.814 \\
\hline Absorption coefticient $\left(\mathrm{mm}^{-1}\right)$ & 12.370 & 32.110 \\
\hline$\theta$ range for data collection (deg) & 2.18 to 24.98 & 1.53 to 24.97 \\
\hline Reflection collected/unique & $\begin{array}{l}3196 / 2609 \\
\left(\mathrm{R}_{\mathrm{Jut}}=0.0250\right)\end{array}$ & $\begin{array}{l}3173 / 1539 \\
\left(\mathrm{R}_{\mathrm{tut}}=0.0483\right)\end{array}$ \\
\hline Goodness of tit on $\mathrm{F}^{2}$ & 1.037 & 1.158 \\
\hline Data/Restraints/Parameters & $2609 / 0 / 152$ & $1539 / 0 / 87$ \\
\hline Final $\mathrm{R}$ indices $\left[\mathrm{F}_{0} \hat{\theta}>2 \sigma\left(\mathrm{F}_{0} \hat{)}\right)\right]^{\sigma}$ & $\begin{array}{l}\mathrm{Rl}=0.0515 \\
\mathrm{wR}_{2}=0.1319\end{array}$ & $\begin{array}{l}\mathrm{RI}=0.0616 \\
\mathrm{wR}_{2}=0.1159\end{array}$ \\
\hline $\mathrm{R}$ indices $\left(\mathrm{F}_{0} \hat{\theta}>0\right)$ & $\begin{array}{l}\mathrm{R} 1=0.0645 \\
\mathrm{wR}_{2}=0.1434\end{array}$ & $\begin{array}{l}\mathrm{RI}=0.1029 \\
\mathrm{w} \mathrm{R}_{2}=0.1394\end{array}$ \\
\hline Largest ditt. peak and hole $\left(\mathrm{e} A^{-3}\right)$ & 3.211 and -1.920 & 4.433 and -5.155 \\
\hline
\end{tabular}

Table 2. Atomic Coordinates $\left(\times 10^{4}\right)$. Occupancy and Equivalent Isotropic Displacement Parameters $\left(\AA^{2} \times 10^{3}\right)$ for $\mathrm{KLa}_{2} \mathrm{Sb}_{3} \mathrm{~S}_{0}$

\begin{tabular}{lrrrrr}
\hline Atoms & x & $y$ & $z$ & $\begin{array}{c}\text { Occupancy } \\
(\%)\end{array}$ & $\mathrm{U}(\mathrm{eq})$ \\
\hline $\mathrm{La}(1)$ & $781(3)$ & $2276(1)$ & $3361(1)$ & 100 & $13(1)$ \\
$\mathrm{La}(2)$ & $235(3)$ & $9001(1)$ & $928(1)$ & 100 & $15(1)$ \\
$\mathrm{Sb}(1)$ & $5415(4)$ & $1864(1)$ & $957(1)$ & 100 & $27(1)$ \\
$\mathrm{Sb}(2)$ & $9817(3)$ & $9668(1)$ & $4965(1)$ & 100 & $19(1)$ \\
$\mathrm{Sb}(3)$ & $4370(4)$ & $8477(1)$ & $3343(1)$ & 100 & $21(1)$ \\
$\mathrm{S}(1)$ & $5253(13)$ & $9799(2)$ & $1398(3)$ & 100 & $16(1)$ \\
$\mathrm{S}(2)$ & $5562(13)$ & $1579(2)$ & $2536(3)$ & 100 & $17(1)$ \\
$\mathrm{S}(3)$ & $9377(13)$ & $1328(2)$ & $4560(3)$ & 100 & $16(1)$ \\
$\mathrm{S}(4)$ & $5474(12)$ & $3170(2)$ & $3257(3)$ & 100 & $14(1)$ \\
$\mathrm{S}(5)$ & $9765(18)$ & $9117(2)$ & $2964(3)$ & 100 & $31(1)$ \\
$\mathrm{S}(6)$ & $6417(12)$ & $2029(2)$ & $4822(3)$ & 100 & $16(1)$ \\
$\mathrm{S}(7)$ & $670(2)$ & $9761(2)$ & $9363(4)$ & 100 & $39(2)$ \\
$\mathrm{S}(8)$ & $9690(7)$ & $2645(5)$ & $1376(7)$ & 51 & $20(6)$ \\
$\mathrm{S}(10)$ & $1180(8)$ & $2612(5)$ & $1388(7)$ & 49 & $14(5)$ \\
$\mathrm{S}(9)$ & $1400(2)$ & $1116(13)$ & $506(11)$ & 50 & $19(9)$ \\
$\mathrm{S}(11)$ & $0(2)$ & $1172(8)$ & $538(10)$ & 50 & $22(9)$ \\
$\mathrm{K}(1)$ & $153(13)$ & $521(2)$ & $2589(3)$ & 100 & $28(1)$ \\
\hline
\end{tabular}

$\mathrm{U}(\mathrm{eq})$ is defined as one-third of the trace of the orthogonalized $\mathrm{U}_{1 \mathrm{j}}$ tensor.

from the reaction product in $\mathrm{NaCl} / \mathrm{KCl}$ flux and its crystal structure was determined by the single crystal X-ray diffraction method. The observed Laue symmetry and systematic extinction suggested the space groups Pna2 ${ }_{1}$ and Pnma. Subsequent refinements confimed the centrosymmetric space group Puma. The final cycle of refinement performed on $F_{0}^{2}$ with 1539 unique reflections converged to residuals $w_{2}\left(F_{i j}{ }^{2}>0\right)=0.1394$ and a conventional $R$ index based on the reflections having $\mathrm{F}_{i j}{ }^{2}>2 \sigma\left(\mathrm{F}_{i}{ }^{3}\right) 0.0616$. The complete data collection parameters. structure solution details and refinement results are given in Table 1 . The final atomic positions, displacement parameters. and isotropic displacement parameters are given in Table 4. Selected bond distances and angles are listed in Table 5.

\section{Results and Discussion}

$\mathrm{KLa}_{2} \mathrm{Sb}_{3} \mathrm{~S}_{9} . \mathrm{KLa}_{2} \mathrm{Sb}_{2} \mathrm{~S}_{9}$ has a three-dimensional tunnel framework with dumbbell-shaped channels, and $\mathrm{K}^{+}$ions are stabilized at the two ends of the channels. The channels run parallel to the a-axis and are linked to each other by $\mathrm{La}^{3-}$ centered infinite rods with a shield-shaped cross-section, as shown Figure 1. The coordination geometry of $\mathrm{La}(\mathrm{l})$ is a tricapped trigonal prism with the La(1)-S distances in the range of $2.895(5)-3.265(5) \AA$. One of the capping sulfur atoms, $S(3)$. forms a $S-S$ dimer with one of prismatic sulfur atoms, $S(6)$, at a distance of $2.139(7) \AA$; this is in the range of typical dimeric $\mathrm{S}-\mathrm{S}$ bond distance. a range of $2.096(5)$ 2.14(1) $\AA^{789}$ (Fig. 2(a)). La(2) has a coordinative environment similar to that of $\mathrm{La}(1)$, where the $\mathrm{La}(2)-\mathrm{S}$ distance is in the range of 2.915(5)-3.358(5) $\AA$ (Fig. 2(b)). The same $\mathrm{S}(3)-\mathrm{S}(6)$ dimer is shared by $\mathrm{La}(1)$ and $\mathrm{La}(2)$-centered polyhedra: hence. the formula of the compound could be 
Table 3. Selected Bond Distances $(\mathcal{A})$ and Angles $\left({ }^{\circ}\right)$ for $\mathrm{KLa}_{2} \mathrm{Sb}_{3} \mathrm{~S}_{9}$

\begin{tabular}{|c|c|c|c|}
\hline $\mathrm{La}(1)-\mathrm{S}(2)$ & $2.895(5), 3.027(5)$ & Lat $(1)-S(6)$ & $\begin{array}{l}2.897(5), 3.176(5) \\
3.265(5)\end{array}$ \\
\hline $\mathrm{La}(1)-\mathrm{S}(4)$ & $2.933(5), 3.114(5)$ & $\operatorname{Lat}(1)-S(3)$ & $2.953(5)$ \\
\hline $\mathrm{La}(1)-\mathrm{S}(10)$ & $3.027(11)$ & $\operatorname{Lat}(1)-S(8)$ & $3.096(13)$ \\
\hline $\operatorname{La}(2)-S(3)$ & $2.915(5), 3.142(5)$ & $\operatorname{La}(2)-S(1)$ & $2.934(5), 2.945(5)$ \\
\hline $\mathrm{La}(2)-\mathrm{S}(7)$ & $2.956(6)$ & $\operatorname{La}(2)-S(4)$ & $2.958(5), 3.358(5)$ \\
\hline $\mathrm{La}(2)-\mathrm{S}(5)$ & $3.023(5)$ & La( 2$)-S(6)$ & $3.055(5)$ \\
\hline $\mathrm{Sb}(1)-\mathrm{S}(2)$ & $2.430(5)$ & $S(x(1)-S(9)$ & $2.56(4), 3.176(70)$ \\
\hline $\mathrm{Sb}(1)-\mathrm{S}(11)$ & $2.61(7), 2.91(7)$ & $S b(1)-S(10)$ & $2.62(3), 3.096(28)$ \\
\hline $\mathrm{Sb}(1)-\mathrm{S}(8)$ & $2.682(19), 3.216(24), 3.655(11)$ & $S b(2)-S(1)$ & $2.477(5)$ \\
\hline $\mathrm{Sb}(2)-\mathrm{S}(7)$ & $2.513(7), 2.838(8)$ & $S b(2)-S(9)$ & $2.59(7), 3.332(69)$ \\
\hline $\mathrm{Sb}(2)-\mathrm{S}(11)$ & $2.993(59), 3.100(61)$ & $S b(2)-S(5)$ & $3.238(5)$ \\
\hline $\mathrm{Sb}(3)-\mathrm{S}(4)$ & $2.476(5)$ & $S(x)-S(5)$ & $2.544(7), 2.807(7)$ \\
\hline $\mathrm{Sb}(3)-\mathrm{S}(8)$ & $2.67(3), 3.239(24)$ & $S b(3)-S(10)$ & $2.84(2), 3.163(26)$ \\
\hline $\mathrm{Sb}(3)-\mathrm{S}(9)$ & $3.356(20)$ & & \\
\hline$S(3)-S(6)$ & $2.139(7)$ & & \\
\hline $\mathrm{K}(1)-\mathrm{S}(2)$ & $3.207(7), 3.427(7)$ & $K(1)-S(1)$ & $3.227(7), 3.281(7)$ \\
\hline $\mathrm{K}(1)-\mathrm{S}(7)$ & $3.229(9), 3.655(9)$ & $K(1)-S(9)$ & $3.435(18)$ \\
\hline $\mathrm{K}(1)-\mathrm{S}(5)$ & $3.440(7)$ & $\mathrm{K}(1)-\mathrm{S}(3)$ & $3.515(7)$ \\
\hline$S(2)-S b(1)-S(9)$ & $93.8(4)$ & $\mathrm{S}(2)-\mathrm{Sb}(1)-\mathrm{S}(8)$ & $87.8(3), 178.81(20)$ \\
\hline$S(2)-S b(1)-S(11)$ & $91.6(3)$ & $\mathrm{S}(2)-\mathrm{Sb}(1)-\mathrm{S}(10)$ & $88.8(3)$ \\
\hline$S(9)-S b(1)-S(8)$ & $178.1(11)$ & $S(10)-S b(1)-S(11)$ & $175.9(13)$ \\
\hline$S(1)-S b(2)-S(9)$ & $97.1(4)$ & $\mathrm{S}(7)-\mathrm{Sb}(2)-\mathrm{S}(9)$ & $92.7(11)$ \\
\hline $\mathrm{S}(7)-\mathrm{Sb}(2)-\mathrm{S}(7)$ & $104.0(2)$ & $\mathrm{S}(1)-\mathrm{Sb}(2)-\mathrm{S}(5)$ & $175.95(31)$ \\
\hline$S(4)-S b(3)-S(5)$ & $89.57(16), 87.32(16)$ & $S(5)-S b(3)-S(5)$ & $104,00(18)$ \\
\hline$S(8)-S b(3)-S(5)$ & $164.6(5)$ & $\mathrm{S}(4)-\mathrm{Sb}(3)-\mathrm{S}(9)$ & $164.6(5)$ \\
\hline
\end{tabular}

Table 4. Atomic Coordinates $\left(\times 10^{\dagger}\right)$, Occupancy and Equivalent Isotropic Displacement Parameters $\left(\AA^{2} \times 10^{3}\right)$ for $\mathrm{KSm}_{2} \mathrm{Sb}_{3} \mathrm{Se}_{8}$

\begin{tabular}{cccccc}
\hline Atomins & $x$ & $y$ & $z$ & $\begin{array}{c}\text { Occupancy } \\
(\%)\end{array}$ & $U(\mathrm{eq})$ \\
\hline $\operatorname{Sm}(1)$ & $5356(1)$ & 2500 & $5896(1)$ & 100 & $18(1)$ \\
$\operatorname{Sm}(2)$ & $7095(1)$ & 7500 & $4549(1)$ & 100 & $19(1)$ \\
$\operatorname{Sb}(1)$ & $8556(1)$ & 2500 & $6007(1)$ & 100 & $22(1)$ \\
$\operatorname{Sb}(2)$ & $4643(1)$ & 7500 & $7393(1)$ & 100 & $24(1)$ \\
$\operatorname{Sb}(3)$ & $9255(2)$ & 2500 & $411(1)$ & 100 & $39(1)$ \\
$\operatorname{Se}(1)$ & $5951(2)$ & 7500 & $6686(1)$ & 100 & $14(1)$ \\
$\operatorname{Se}(2)$ & $7134(2)$ & 2500 & $5524(1)$ & 100 & $14(1)$ \\
$\operatorname{Se}(3)$ & $8195(2)$ & 7500 & $6759(1)$ & 100 & $19(1)$ \\
$\operatorname{Se}(4)$ & $5323(2)$ & 2500 & $8239(1)$ & 100 & $22(1)$ \\
$\operatorname{Se}(5)$ & $8848(2)$ & 7500 & $4979(1)$ & 100 & $20(1)$ \\
$\operatorname{Se}(6)$ & $5740(2)$ & 2500 & $4576(1)$ & 100 & $15(1)$ \\
$\operatorname{Se}(7)$ & $3941(2)$ & 2500 & $6743(1)$ & 100 & $16(1)$ \\
$\operatorname{Se}(8)$ & $7793(2)$ & 2500 & $3745(1)$ & 100 & $14(1)$ \\
$\mathrm{K}(1)$ & $7948(5)$ & 7500 & $2558(3)$ & 100 & $30(2)$ \\
\hline
\end{tabular}

U(eq) is defined as one third of the trace of the orthogonalized $U_{1 j}$ tensor.

described as $\left(\mathrm{K}^{-}\right)\left(\mathrm{La}^{3-}\right)_{2}\left(\mathrm{Sb}^{3-}\right)_{3}\left(\mathrm{~S}^{--}\right)_{7}\left(\mathrm{~S}_{2}^{2-}\right)$. The coordination environments of $\mathrm{La}$ are much like the ones found in the binary $\mathrm{LnQ}_{2}(\mathrm{Q}=\mathrm{S}$. Se $){ }^{13}$ where the rare-earth metal atom is coordinated to nine chalcogen atoms in a distorted tricapped trigonal prism. The four La-centered shield- shaped rod comprises two La-centered double columns fonned by sharing the $\mathrm{S}(4)$-S(4) edge of two trigonal prisms. Moreover. the two double columns are further condensed in parallel fashion to fonm a quadruple column in which apex sulfur at $S(3)$ in one double column becomes a cap at $S(6)$ in the next double column (Fig. 2(c)). Comparable infinite polyhedron chains are observed in $\mathrm{KThSb}_{2} \mathrm{Se}_{6}{ }_{6}{ }^{8}$ and $\mathrm{K}_{2}(\mathrm{RE})_{2 . .} \mathrm{Sb}_{4-} \mathrm{Se}_{12}$ ( $\mathrm{RE}=\mathrm{La}, \mathrm{Ce}, \mathrm{Pr}, \mathrm{Gd}){ }^{6}{ }^{6} \mathrm{In} \mathrm{KThSb}_{2} \mathrm{Se}_{6}$, Th atoms form onedimensional infinite double columns that run parallel to the (100) direction. In $\mathrm{ALn}_{1 \pm \times} \mathrm{Bi}_{4=\times} \mathrm{S}_{8}$. ${ }^{3}$ quadruple columns also appears. but with a difference: the two neighboring columns are stacked in a perpendicular fashion.

Three crystallographically different $\mathrm{Sb}$ atoms in $\mathrm{KLa}_{2} \mathrm{Sb}_{2} \mathrm{~S}_{9}$ have a formal charge of +3 with five coordinations and form dumbbell-shaped channels. $\mathrm{Sb}(\mathrm{I})$ has five $\mathrm{Sb}$-S bonds ranging from $2.430(5)-2.682(19) \AA$. The $\mathrm{Sb}(1)-\mathrm{S}(8)$ interaction at 3.655 (11) $\AA$ across the tumel is considerably longer than the other five $\mathrm{Sb}(\mathrm{l})-\mathrm{S}$ bond lengths, but still shorter than the sum of the Sb-S van der Waals radii. $4.05 \AA$. ld $d$ Therefore, the local geometry around $S b(1)$ is pseudo-octahedral with one long $\mathrm{Sb}-\mathrm{S}$ interaction. The basal $\mathrm{S}-\mathrm{Sb}(\mathrm{l})$-S angles range from $88.2(7)^{\circ}$ to $95.8(19)^{\circ}$ and the axial $\mathrm{S}-\mathrm{Sb}(1)-\mathrm{S}$ angle is $175.81(20)^{\circ}$ : this is also suitable for distorted octahedral coordination. $\mathrm{Sb}(2)$ and $\mathrm{Sb}(3)$ atoms have coordinate characters similar to that of the $\mathrm{Sb}(\mathrm{l})$ atom with five shorter $\mathrm{Sb}-\mathrm{S}$ bonds at a distance of 2.477(5)-2.993(59) $\AA$ for $\mathrm{Sb}(2)$ and 2.476(5)-2.807(7) $\AA$ for $\mathrm{Sb}(3)$. The longer $\mathrm{Sb}$ - $\mathrm{S}$ bonds at $3.238(5) \AA$ and $3.356(20) \AA$ also exist around $\mathrm{Sb}(2)$ and $\mathrm{Sb}(3)$, respectively. The basal bond angles are 90.25(16)$104.0(2)^{\circ}$ in $\mathrm{Sb}(2) \mathrm{S}_{6}$ and 81.3(3)-104.00(18) in $\mathrm{Sb}(3) \mathrm{S}_{6}$, and 
Table 5. Sclected Bond Distances $(A)$ and Angles (" $)$ for $\mathrm{KSm}_{2} \mathrm{Sb}_{3} \mathrm{Sc}_{8}$

\begin{tabular}{|c|c|c|c|}
\hline $\operatorname{Sin}(1)-\operatorname{Se}(1)$ & $2.883(2) \times 2$ & $\operatorname{Sin}(1)-\operatorname{Se}(6)$ & $2.950(2) \times 2.2 .993(3)$ \\
\hline $\operatorname{Sin}(1)-\operatorname{Se}(7)$ & $3.020(3)$ & $\operatorname{Sin}(1)-\operatorname{Se}(2)$ & $3.085(3)$ \\
\hline $\operatorname{Sin}(2)-\operatorname{Se}(8)$ & $2.964(2) \times 2$ & $\operatorname{Sin}(2)-\operatorname{Se}(2)$ & $2.987(2) \times 2$ \\
\hline $\operatorname{Sin}(2)-\operatorname{Se}(6)$ & $3.063(3) \times 2$ & $\operatorname{Sin}(2)-\operatorname{Se}(5)$ & $3.082(4)$ \\
\hline $\operatorname{Sin}(2)-\operatorname{Se}(7)$ & $3.345(3)$ & & \\
\hline$S b(1)-S e(2)$ & $2.606(4)$ & $S b(1)-S e(3)$ & $2.719(3) \times 2$ \\
\hline$S b(1)-S e(5)$ & $3.110(3) \times 2$ & $S b(1)-S e(4)$ & $3.394(4)$ \\
\hline$S b(2)-S e(1)$ & $2.689(4)$ & $S b(2)-S e(7)$ & $2.774(3) \times 2$ \\
\hline$S b(2)-S e(4)$ & $3.010(3) \times 2$ & $\mathrm{Sb}(2)-\mathrm{Se}(3)$ & $3.064(4)$ \\
\hline$S b(3)-S e(8)$ & $2.575(4)$ & $\mathrm{Sb}(3)-\mathrm{Se}(5)$ & $2.900(3) \times 2.3 .758(4)$ \\
\hline$S b(3)-S e(4)$ & $2.913(3) \times 2$ & & \\
\hline$K^{\prime}(1)-S e(4)$ & $3.261(9)$ & $K(I)-S e(3)$ & $3.322(6) \times 2$ \\
\hline$K(1)-S e(8)$ & $3.352(6) \times 2$ & $K(1)-S e(1)$ & $3.371(6) \times 2$ \\
\hline$K^{\prime}(1)-\operatorname{Se}(7)$ & $3.517(8)$ & & \\
\hline $\operatorname{Se}(2)-S b(1)-S e(3)$ & $92.84(10)$ & $\operatorname{Se}(3)-\operatorname{Sb}(1)-\operatorname{Se}(3)$ & $98.65(12)$ \\
\hline$S e(3)-S b(1)-S e(5)$ & $88.89(6) .170 .49(1)$ & $\operatorname{Se}(2)-\operatorname{Sb}(1)-\operatorname{Se}(4)$ & $174.76(12)$ \\
\hline$S e(5)-S b(1)-S e(5)$ & $83.05(0)$ & $\mathrm{Se}(7)-\mathrm{Sb}(2)-\mathrm{Se}(7)$ & $96.00(12)$ \\
\hline $\operatorname{Se}(7)-\operatorname{Sb}(2)-\operatorname{Se}(4)$ & $172.67(11) .88 .49(6)$ & $\mathrm{Se}(4)-\mathrm{Sb}(2)-\mathrm{Se}(4)$ & $86.48(11)$ \\
\hline$S e(1)-S b(2)-S e(3)$ & $177.74(13)$ & $\operatorname{Se}(7)-\operatorname{Sb}(2)-\operatorname{Se}(3)$ & $89.08(9)$ \\
\hline $\operatorname{Se}(8)-\operatorname{Sb}(3)-\operatorname{Se}(5)$ & $89.21(11), 165.96(13)$ & $S e(5)-S b(3)-S e(5)$ & $90.61(13)$ \\
\hline$S e(5)-S b(3)-S e(4)$ & $179.51(13) .89 .63(6)$ & $S e(4)-S b(3)-S e(4)$ & $90.12(12)$ \\
\hline
\end{tabular}

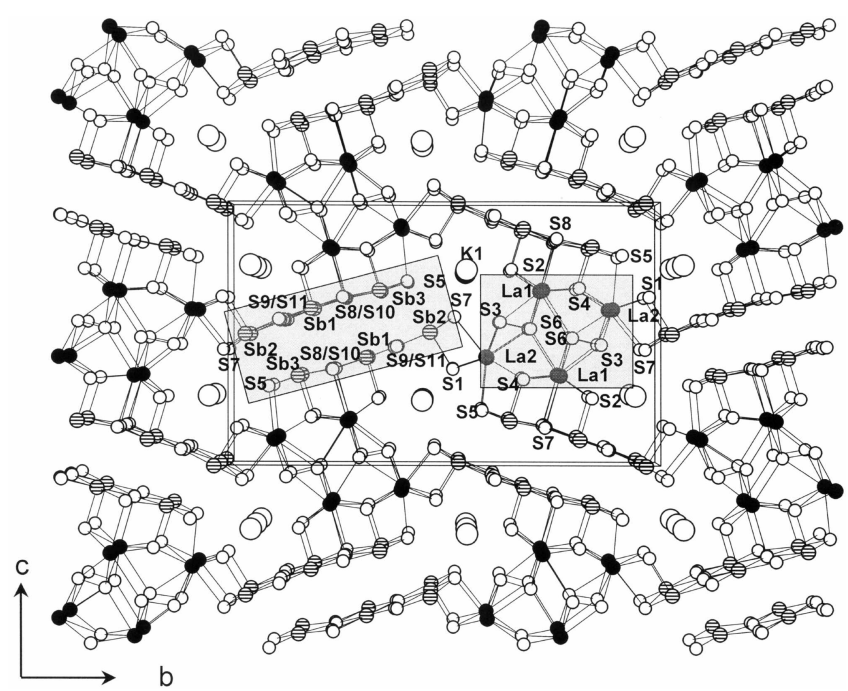

Figure 1. $\Lambda$ perspective view of $\mathrm{KLa}_{2} \mathrm{Sb}_{3} \mathrm{~S}$, down the a-axis with the atom labeling. Dumbhell-shaped tunnels. $S(3)-S(6)$ dimers. and the unit cell boundary are shown. The $\mathrm{Gd}_{2} \mathrm{~S}_{3}$-ty pe and VaCl-type building blocks are shacked.

the axial angles are $172.81(14)^{\circ}$ for $\mathrm{Sb}(2) \mathrm{S}_{6}$, and $175.95(31)^{\circ}$ for $\mathrm{Sb}(3) \mathrm{S}_{t,}$. The distorted environments around $\mathrm{Sb}$ atoms indicate that the $5 \mathrm{~s}$ lone pair electrons in $\mathrm{Sb}$ is stereochemically expressed and is directed toward the longer Sb-S bonds. "This type of Sb-S coordination is present in $\mathrm{Sb}_{2} \mathrm{~S}_{3}{ }^{14}$ $\mathrm{Cs}_{2} \mathrm{Sb}_{4} \mathrm{~S}_{8}{ }^{\text {lid)}}$, and $\mathrm{K}_{2}(\mathrm{RE})_{2-4} \mathrm{Sb}_{4} \mathrm{~S}_{4} \mathrm{Se}_{2}(\mathrm{RE}=\mathrm{La}, \mathrm{Ce}, \mathrm{Pr}, \mathrm{Gd})^{6}$

The potassium atoms observed are coordinated by nine sulfur atoms in a tricapped trigonal prismatic site with an average $\mathrm{K}-\mathrm{S}$ distance of $3.379(9) \AA . \mathrm{KLa}_{2} \mathrm{Sb}_{3} \mathrm{~S}_{9}$ and $\mathrm{KSm}_{2} \mathrm{Sb}_{3} \mathrm{Se}_{8}$ seem to be closely related in their structure and empirical formula. However, they differ in that $\mathrm{KLa}_{2} \mathrm{Sb}_{3} \mathrm{~S}_{9}$ contains chalcogen-chalcogen bonds in shield-shape rods; this is not found in $\mathrm{KSm}_{2} \mathrm{Sb}_{3} \mathrm{Se}^{8}$. Such a complex feature with $\mathrm{S}-\mathrm{S}$ bondings in the framework seems to be related to a larger size difference between $I$,a and $S$ atoms.

$\mathbf{K S m} \mathbf{S b}_{3} \mathrm{Se}_{8} . \mathrm{KSm}_{2} \mathrm{Sb}_{3} \mathrm{Se}_{8}$ has a three-dimensional tumnel framework consisting of $\mathrm{Gd}_{2} \mathrm{~S}_{3}$-type and $\mathrm{NaCl}$-type fragments, as shown Figure 3. The shield-shaped $\mathrm{Gd}_{2} \mathrm{Se}_{3}$-type chain contains two columns of 7-coordinate $\operatorname{Sm}(1)$-centered chain and two columns of 8 -coordinate $\operatorname{Sm}(2)$-centered chain. The local geometry of $\operatorname{Sm}(1)$ is a distorted monocapped trigonal prism, and the distance between $\operatorname{Sin}(1)$ and Se atoms is in the range of $2.883(2)-3.085(3) \AA$, where $\mathrm{Se}(7)$ at $3.020 \AA$ is described as a capping atom (Figure $4(a)$ ). On the other hand, the $\operatorname{Sin}(2)$ is located at the center of a distorted bicapped trigonal prism. The distances between $\mathrm{Sm}(2)$ and prismatic Se atoms are in the range of 2.964(2)$3.063(3) \AA$. while the two capping $\operatorname{Se}(5)$ and $\operatorname{Se}(7)$ atoms are bonded to $\operatorname{Sm}(2)$ at distances of 3.083(4) $\AA$ and $3.345(3) \AA$, respectively (Figure $4(\mathrm{~b})$ ). The two monocapped prisms stack by sharing their $\mathrm{Se}(1)-\mathrm{Se}(6)$ edges, while the two bicapped prisms stack by sharing their $\mathrm{Se}(2)-\mathrm{Se}(6)-\mathrm{Se}(8)$ trigonal faces. The two different kinds of prisms are piled and thereby create infinite rods in the $(010)$ direction (see rigure 4(c)). A similar infinite rod was found in $\mathrm{Ln}_{2} \mathrm{Q}_{3}(\mathrm{Ln}$ $=$ Gd, La, Sm; Q=S, Se). ${ }^{15}$

The rectangular-shaped $\mathrm{NaCl}$-type fragments in this compound are made up of three crystallographic different $\mathrm{Sb}^{3+}$ atoms. $\mathrm{Sb}(\mathrm{l})$-centered polyhedra have three shorter Sb-Se bonds (2.606(4)-2.719(3) $\AA$ ) and three longer bonds $(3.110(3)-3.394(4) \AA)$; this suggests that the coordination environment of $\mathrm{Sb}(1)$ is intermediate between a trigonal bipyramid and an octahedron. However, the longest Sb(1)-Se distance at 3.394(4) $\AA$ is shorter than the sum of 


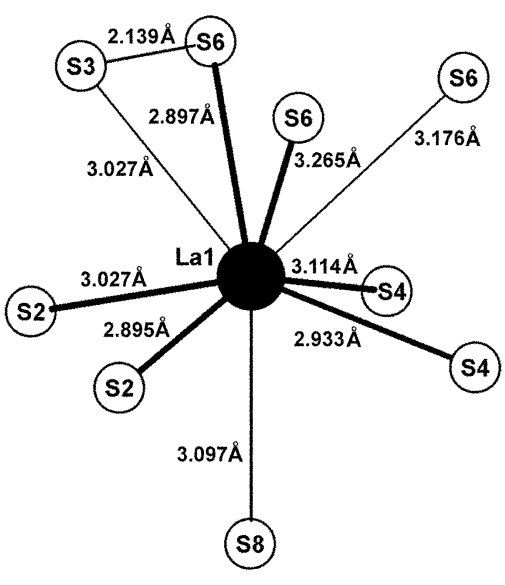

(a)

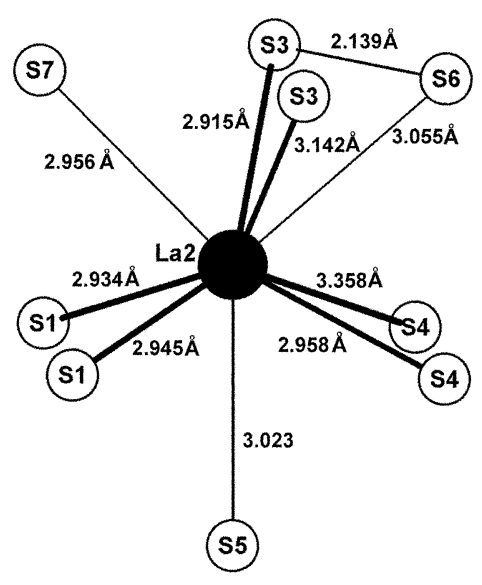

(b)

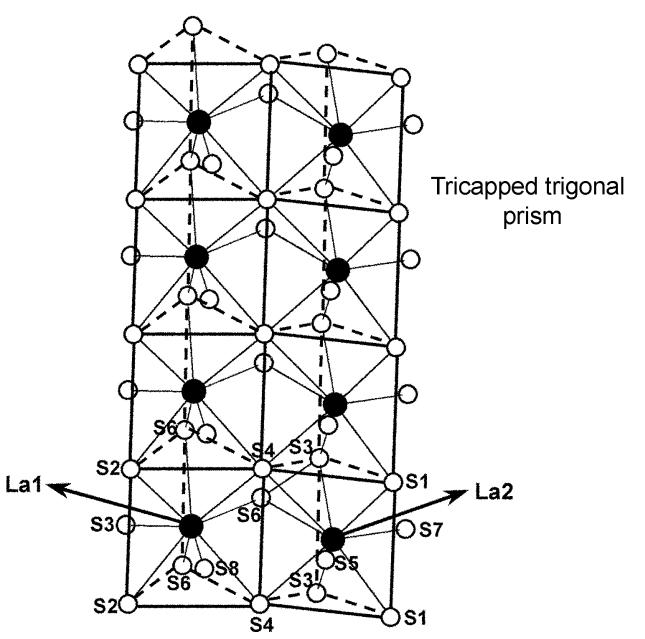

(c)

Figure 2. (a) Local coordination of La(I) with the bond distances $(A)$ in $\mathrm{KLa} \mathrm{A}_{2} \mathrm{Sb}_{3} \mathrm{~S}_{\%}$. One of the capping $\mathrm{S}$ atoms. $\mathrm{S}(3)$ is bonded to a prismatic sulfur atom $S(6)$ at $2.139 \mathrm{~A}$. $S(6)$ and $S(8)$ arc capping sulfur atoms. (b) The local coordination of La(2) with the bond distances (A). The same $S(3)-S(6)$ dimer is shared by $L, a(1)$ and $l$ a( 2$)$-centered poly hedra. $S(6)$ al $3.055 \AA$. $S(5)$. and $S(7)$ are capping sulfur aloms. (c) The orientalion of wo la-centered double columns made of two $L$ a 1 ( S S and I a $(2) S$, polyhedron.

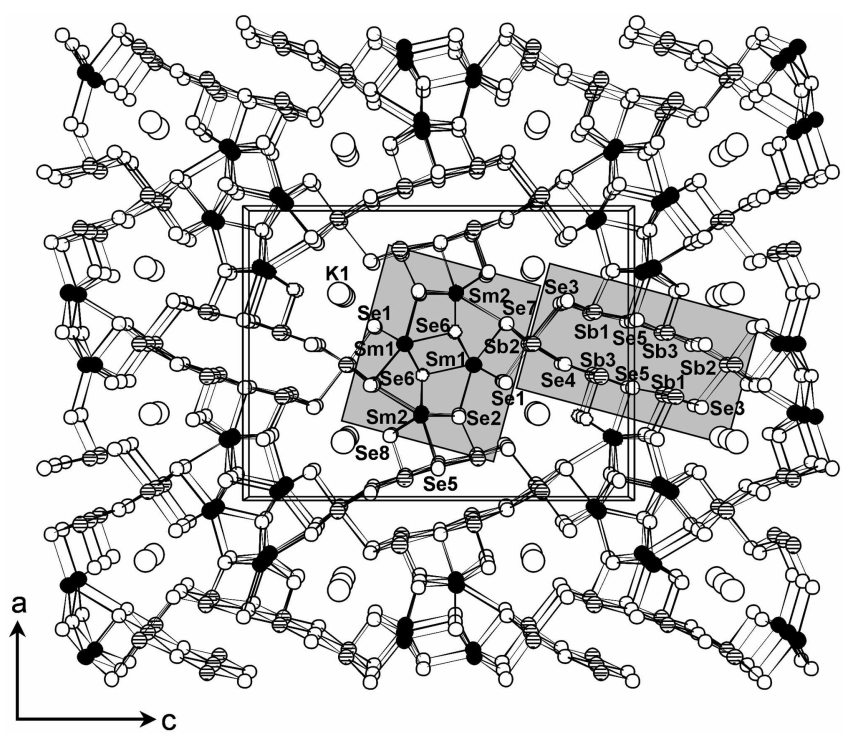

Figure 3. $\Lambda$ perspective view of $K \mathrm{Sm}_{2} S b_{3} \mathrm{Se}_{3}$ down the b-axis with the atom-labeling sehwe. The $\mathrm{K}^{\prime}$ stabilized tunnels and rectangular shaped tumnels are shown. The unit cell boundary is also shown. The $\mathrm{Gid} \mathrm{S}_{3}$-type and $\mathrm{VaCl}$-lype building blocks are shaded.

the Sb-Se van der Waals radii, $4.20 \AA .^{16}$ Therefore, the local geometry of $\mathrm{Sb}(1)$ can be regarded as a pseudo octahedron rather than a trigonal pyramid. The basal $\mathrm{Se}-\mathrm{Sb}(1)-\mathrm{Se}$ angles range from $83.05^{\circ}$ to $102.91^{\circ}$, and the axial bond angle is $174.76(12)^{\circ}$, so it is reasonable to regard this as a distorted octahedral coordination. In $\mathrm{Sb}(2)$-centered polyhedra, all Sb-Se bonds are in the normal range, 2.689(4)-3.064(4) $\AA$, with three shorter bonds. The $\mathrm{Sb}(3)$-centered polyhedron seems to form a octahedron with one square plane and two apexes. The $\mathrm{Sb}(3)$-Se bonds in the square plane is $2.900(3)$ $\AA$ and $2.913(3) \AA$, while the $\operatorname{Sb}(3)$-one apex $\operatorname{Se}(8)$ is $2.575(4) \AA ; \mathrm{Sb}(3)$-the other apex-Se(5) is $3.758(4) \AA$, shorter than $4.20 \AA$. In addition, the bond angles are $89.1(11)-91.22(11)^{\circ}$ in the basal plane and the axial bond angle is $163.93^{\circ}(13)$ around $\mathrm{Sb}(3)$. Thus it is also reasonable that the local geometry of $\mathrm{Sb}(3)$ is distorted octahedral, such as in the $\mathrm{Sb}(1) \mathrm{Se}_{\mathrm{f}}$ octahedra. That the distorted enviromments around $\mathrm{Sb}$ atoms involved $5 \mathrm{~s}$ lone pair electrons of $\mathrm{Sb}$ was stereochemically expressed and tended toward the longer $\mathrm{Sb}$-Se bonds." The $\mathrm{Sb}(1) \mathrm{Se}_{6}, \mathrm{Sb}(2) \mathrm{Se}_{6}$ and $\mathrm{Sb}(3) \mathrm{Se}_{6}$ octahedra were alternatively located by sharing $S e$ atoms in the basal planes to form a rectangular-shaped tunnel running along the b-axis (Figure 3). This kind of fragment is prevalent in $\mathrm{M}_{2} \mathrm{Q}_{3}$ $(\mathrm{M}=\mathrm{As}, \mathrm{Sb}, \mathrm{Bi} ; \mathrm{Q}=\mathrm{S}, \mathrm{Se}, \mathrm{Te})^{17}$ and also found in $\mathrm{Cs}_{2} \mathrm{Sb}_{4} \mathrm{Se}_{8}{ }^{18}$ and $\mathrm{K}_{2}(\mathrm{R} \Gamma)_{2-1} \mathrm{Sb}_{41 \times} \mathrm{Se}_{12}\left(\mathrm{RT}=\mathrm{I}_{\text {a }}, \mathrm{Ce}, \mathrm{Pr}, \mathrm{Gd}\right)$.

The shield-shaped infinite rods and rectangular-shaped tunnels connect to each other through $\mathrm{Sb}(2)$ atoms to build up $\mathrm{K}^{+}$-filled tunnels. $\mathrm{K}^{+}$ions are coordinated with eight $\mathrm{Se}$ atoms in the range of $3.26 \mathrm{~J}(9)-3.517(8) \AA$ to form distorted bicapped trigonal prisms. $\mathrm{KSm}_{2} \mathrm{Sb}_{3} \mathrm{Se}_{8}$ has structural features similar to those of $\mathrm{ALn}_{1} \ldots \mathrm{Bi}_{4}, \mathrm{~S}_{8}(\mathrm{~A}=\mathrm{K}, \mathrm{Rb} ; \mathrm{Ln}=\mathrm{La}, \mathrm{Ce}$, $\mathrm{Pr}, \mathrm{Nd}){ }^{12} \mathrm{Gd}_{2} \mathrm{~S}_{3}{ }^{10}$ and $\mathrm{NaCl}$-type fragments in $\mathrm{KS} \mathrm{Sm}_{2} \mathrm{Sb}_{3} \mathrm{Se}_{8}$ have the same structural feature as do those in $\mathrm{KLa}_{1} 、 \mathrm{Bi}_{4}, \mathrm{~S}_{8}$. The only difference in the two compounds is the disorders between $\mathrm{Ln}$ and $\mathrm{Bi}$ atoms; this disorder results in nonstoichiometric composition in $A L n_{1}, B i_{4}, \gamma S_{S_{.}}$. However, no partial occupancy and disorder in the Sm and $\mathrm{Sb}$ atom sites were detected in $\mathrm{KSm}_{2} \mathrm{Sb}_{3} \mathrm{Se}_{3}$. The ionic radii of $\mathrm{La}^{3+}$ and $\mathrm{Bi}^{3+}$ are in the ranges of $1.10-1.160 \AA$ and $0.96-$ $1.03 \AA$, respectively, while those of $\mathrm{Sm}^{3+}$ and $\mathrm{Sb}^{3-}$ are in the range of 1.02-1.079 $\AA$ and $0.76-0.80 \AA$, respectively..$^{20}$ The disorder and mixed occupancy in the $\mathrm{Ln}$ and $\mathrm{Bi}$ sites in $\mathrm{ALn}_{1}, \mathrm{Bi}_{4} \ldots \mathrm{S}_{8}$ and ordered ideal structure of $\mathrm{KSm} \mathrm{m}_{2} \mathrm{Sb}_{3} \mathrm{Se}_{8}$ can be understood in terms of the size differences of the two cations, $\mathrm{Sm}$ and $\mathrm{Sb}$.

In summary, $\mathrm{KSm}_{2} \mathrm{Sb}_{3} \mathrm{Se}_{8}$ and $\mathrm{KLa}_{2} \mathrm{Sb}_{3} \mathrm{~S}_{9}$ commonly consist of $\mathrm{Gd}_{2} \mathrm{~S}_{3}$-type and $\mathrm{NaCl}$-type fragments. $\mathrm{KSm}_{2} \mathrm{Sb}_{3} \mathrm{Se}_{8}$ 


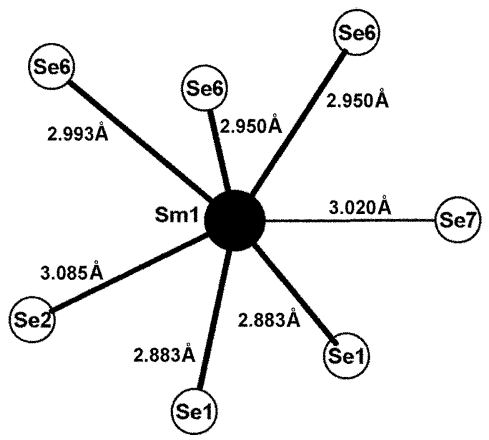

(a)

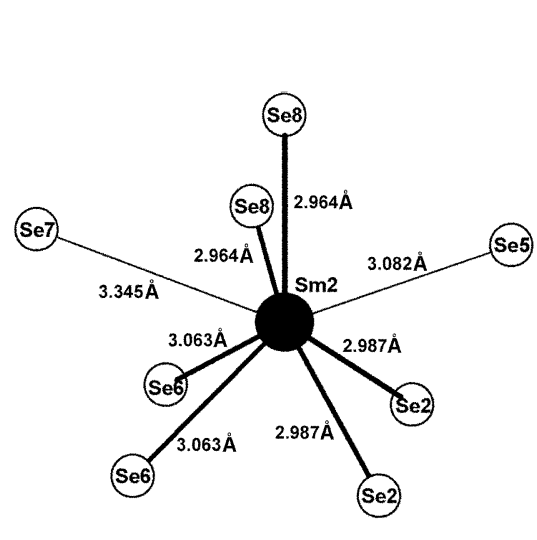

(b)

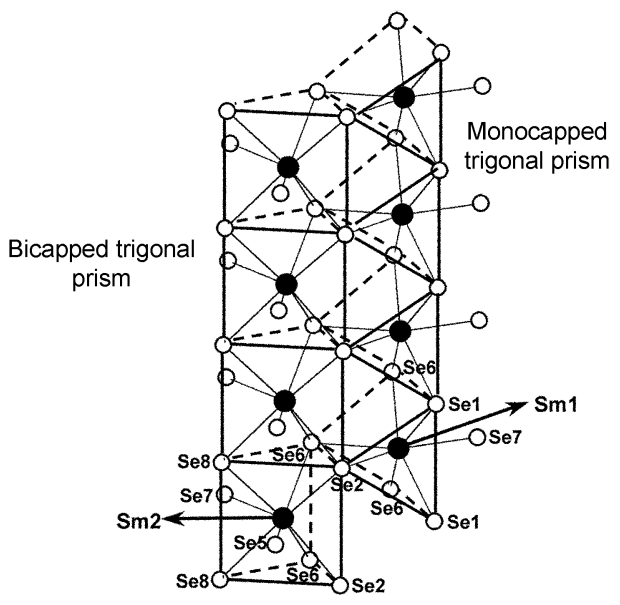

(c)

Figure 4. (a) L.ocal coordination or $\operatorname{Sm}(I)$ with the bond distances $(A)$ showsing the monocapped trigonal prism. $S e$ (7) is a capping atom. (b) The local coordination of $\operatorname{Sm}(2)$ wijh the bond distances $(X)$ showing the bicapped trigonal prism. $\mathrm{Se}(7)$ and $\mathrm{Se}(5)$ are capping atoms. (c) The oricntation of the two La-centered double columns consisted of two monocapped and two bicapped trigonal prisms.

phase is an ordered phase of $\mathrm{Kl}_{\mathrm{a}_{1}-\mathrm{x}} \mathrm{Bi}_{4+}, \mathrm{S}_{8}$, and is due to the larger size differences of the two cations of $\mathrm{Sm}$ and $\mathrm{Sb}$. $\mathrm{KL} \mathrm{a}_{2} \mathrm{Sb}_{3} \mathrm{~S}$, is a derivative of $\mathrm{KSm_{2 }} \mathrm{Sb}_{3} \mathrm{Se}_{8}$ where $\mathrm{S}-\mathrm{S}$ dimers exist in a $\mathrm{Gd}_{2} \mathrm{~S}_{3}$-type fragment. $\mathrm{KL} \mathrm{La}_{2} \mathrm{Sb}_{3} \mathrm{~S}_{\text {, demonstrates that }}$ the strategy of adding larger rare earth metals to a $\left(\mathrm{Sb}_{\mathrm{x}} \mathrm{Q}_{3}\right)^{\mathrm{n}-}$ building block results in a more complex structure through the fine-tuming of the $\left(S b_{3} Q_{y}\right)^{1-}$ building block. Therefore, many more new $(\mathrm{Sb}, \mathrm{Q},)^{\mathrm{n}-}$ building blocks could be prepared using a similar approach.

Acknowledgements. This work is supported from Korea Research Foundation Grant (KRF-2000-015-DP0224).

\section{References}

1. (a) Docrsscheidt. W. Shäfer. II, Z. Batuforsh, 1981, 36B. 410. (b) Cordier. (i.: Sclü̈ler. IL. Rev: Chim. Winer: 1981. 18.218. (c) Eisenmann. B.: Schafer. H. 7.. Naturforsch. 1979. 34B. 383. (d) McCarthy. L. J.: Kanatzidis. M. G. horg. Chem. 1994. 33. 1205.

2. (a) Smith. P. P. K.: Hyde, B. G. Aeta 'ryst. 1983. ('39. 1498. (b) Skowron, A. Brown. I. D. feter Cinst 1990, (46.527.

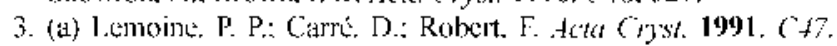
938. (b) Wacker. K.: Salk. M.: Decker-Schultheiss. (i.: Keller. I: 7. Anorg. Allg (hent 1991. 606. 51 . (c) Odink. D. A.: Carteaux. V.: Paye1. C.: Ouvrard. G. Chem Mater 1993. 5. 237.

4. Oljvicr-Fourcade. J: lbanez. A.: Jumas. J. C.: Maurin. M.: I fefubve. I.: I ippens. P.: I annoo. M.: Allan. (i. J. Sold State Chen. 1990, 87,366

5. (a) Rustamov. P. (j.: Khasaev. I. P.: Aliek: (). M. Morg, Mater:
1981. 77. 1469. (b) Alicv, O. M.: Maksudovat T. F.: Samsonova. N. D.: Finkelshtein. I. I).: Rustamov, P. (i. Inorg, Water: 1986. 2.. 23. (c) Alieva. L. (j.: Khasaev. D. P.: Namazov. F. A.: Aliev. F. G.: Aliev. O. M. Russ. J. Inorg. Chem. 1988. 33.914.

6. Chen. J. H.: Dorhout. P. H. J. Alloys and Compds. 1997. 24\%. 199.

7. Choi, K.-S.: Kanatzidis. .M. G, Chem. Hatet: 1999, /1, 2613.

8. Choi, K.-S.: Iordanidis. 1..: Chondroudis. K.: Kanatzidis. M. (i. Inorg. Chem. 1997. 36. 3804.

9. Choi. K.-S.: Hanko. J. A.: Kanalzidis. M. G. J. Sold State Chen. 1999. 147.309

10. Park. S.: Kim. S.-I. J. Solld Sitate Chem. 2001. 16/. 129.

11. Chung. D.-Y.: lordanidis. I., Choi, K.-S.: Kanatridis. M, G. Bull. Konean Chem. Soc. 1998. 19. 1283.

12. lordanidis. L.: Schindler. J. L.: Kannewurl. C. R.: Kanatzidis. M. (i. J. Solid State Chen. 1999. H3. $15 \mathrm{I}$

13. (a) Chen. I. H.: Dorhout. P. K. I. Soldt State (hem. 1995. I17. 318. (b) I ces. S.: Foran, B. J Am Chem. Soc: 1994. 116. 154.

14. Iloftimann. W. 7., Z. Aristallogt: 1933, \$6. 225.

15. (a) Schleid. T. Z. Anorg, Allg. Chew. 1990. III. (b) Cirundmeier. J.: Urland. W. Z. Anorg. Allg Chem 1992. 1977.

16. Tideswell. N. W.: Kruse. F. H.: MeCullough. J. D. Ata Cryst. 1957. 10.99.

17. (a) Sinith, M. J.: Knight, R. J.: Spencer, C. W. J. Appl. Plns. 1962. 33. 2186 , (b) Testardi. I. R.: Bierly. J. N. Jr: Donahos, Г. J. J. Phys. Chem. Solds 1962. 23. 1209. (c) Champless. C. Hl: Chiang. I. 1': l'arehh. P. . Ph. Phs 1965. +3. 653. (d) Yim. W. M.: Fitzke. E. V.J. Flectrochem Soc 1968. 175. 556.

18. Sheldrick. W. S.: Kaub. I. Z. Anorg illg (hem. 1989. 536. II4.

19. Prewitt, C. T.: Sleight A. W. Lnorg. Chem. 1968. 7, 1090.

20. Shannom. R. D. Acta Crast. 1976. A32.75I. 